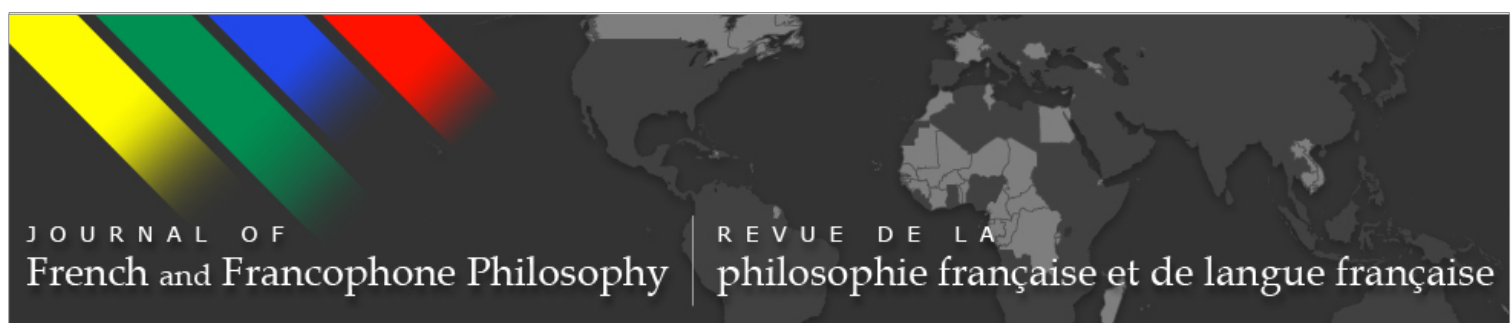

\title{
Praxis and Pragmatism
}

\section{Hugues Dusausoit}

Journal of French and Francophone Philosophy - Revue de la philosophie française et de langue française, Vol XX, No 2 (2012) pp 75-97

\author{
Vol XX, No 2 (2012) \\ ISSN 1936-6280 (print) \\ ISSN 2155-1162 (online) \\ DOI 10.5195/jffp.2012.534 \\ www.jffp.org
}

\section{(oc) EY-NG-ND}

This work is licensed under a Creative Commons Attribution-Noncommercial-No Derivative Works 3.0 United States License.

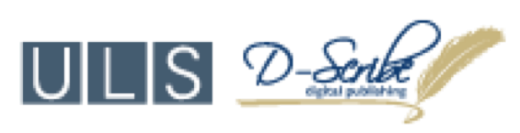

This journal is operated by the University Library System of the University of Pittsburgh as part of its D-Scribe Digital Publishing Program, and is co-sponsored by the University of Pittsburgh Press 


\title{
Praxis and Pragmatism
}

\author{
Hugues Dusausoit \\ University of Namur (Belgium)
}

\section{Introduction}

The connections between Michel Henry's phenomenology of life and pragmatism have never been explored. This might seem surprising given that both share the same aim: to break with the primacy of representation and theory and to return to the primacy of life and praxis. However, the lack of attention to their interconnection might also appear much less surprising if one looks at the way Henry and the pragmatist tradition carry out this shift. While pragmatists usually invite philosophers to stop their quest for foundations, Henry maintains that philosophers have not gone far enough in this quest. This difference inevitably gives the impression that Henry and the pragmatist tradition do not have much in common. Nevertheless, given that they both ultimately have the same aim, it might be worth going beyond first impressions and exploring whether, despite their apparent opposition, the two approaches could not be reassessed more constructively. In order to do so, this article will seek to initiate a dialogue between Michel Henry and Richard Rorty, an author who claims to do with pragmatism what Henry claims to do with phenomenology: radicalize it. ${ }^{1}$ While such radicalization risks underscoring the opposition previously mentioned between Henry and pragmatism, it might also reveal a way to overcome it.

\section{A Common Base: Nietzsche}

Coming as they do from two very different philosophical traditions, Henry and Rorty do not offer many footholds for those who seek to initiate a dialogue between them. But there is at least one, and his name is Nietzsche. While Henry celebrates Nietzsche as one of the few philosophers to have successfully developed a philosophy of life, Rorty considers him the first to have expressed a pragmatist's conception of truth. Comparing Henry and Rorty's readings of Nietzsche therefore seems to be an ideal way to illustrate, and perhaps understand, how their common support for the primacy of life and praxis could have been expressed in such different ways.

Journal of French and Francophone Philosophy | Revue de la philosophie française et de langue française Vol XX, No 2 (2012) | www.jffp.org | DOI 10.5195/jffp.2012.534 
Henry often refers to what distinguishes phenomenology from other sciences. While the latter always focus on a particular phenomenon physical, chemical, biological, historical, sociological, economic, etc. phenomenology questions the very phenomenality of any phenomenon. In other words, it questions what enables a phenomenon to appear. Henry argues that phenomenology has essentially given one answer to this question, and that this answer reveals what has always been implicit in the Western philosophical tradition: an object can appear to a subject because the latter, thanks to its power of transcendence, opens up a horizon in which, at a distance, any object is likely to appear. The importance of Nietzsche, according to Henry, lies in his implicit claim that there is another way of appearing which precedes the power of transcendence and does not depend on it. This is demonstrated by Nietzsche's description of suffering: while I suffer and cannot bear myself anymore, I project myself into the horizon of transcendence with the hope of taking some distance from myself and becoming someone else. Nevertheless, I realize at the same time that this projection is in vain and that I cannot take the slightest step out of myself: "If only I was some other person [...]," writes Nietzsche, "but there is no hope of that, I am who I am [...]." ${ }^{2}$ According to Henry, this failure to escape reminds us that there is, prior to any transcendence, an immediate and absolute revelation of the self to itself. Nietzsche's "Will to power" would, he maintains, only refer to this inevitable ordeal, which no living being can avoid and which constitutes the concrete reality of all feeling. There would therefore be two ways of appearing. The first, called "life" by Henry, refers to this affective, immediate and unquestionable experience that we never stop having of ourselves. The second, called "representation," requires a phenomenological distance between the perceiving subject and the perceived object, since it does not present any reality in itself but only a secondary, and thus dubious, re-presentation of it.

The picture Rorty paints of Nietzsche seems a very different one. While Henry portrays Nietzsche as the philosopher of the absolute self-certainty experienced by any living being, Rorty depicts Nietzsche as a philosopher of contingency. Nietzsche, with his pragmatist conception of truth, would serve to remind us that our representations are linguistic creations, and cannot claim to move beyond their particular context in order to achieve what is traditionally considered as being the truth: "It was Nietzsche who first explicitly suggested that we drop the whole idea of 'knowing the truth'. His definition of truth as a 'mobile army of metaphors' amounted to saying that the whole idea of 'representing reality' by means of language, and thus the idea of finding a single context for all human lives, should be abandoned." ${ }^{3}$ The contrast with Henry's reading of Nietzsche appears obvious when this philosophy of contingency is extended to the subject. Indeed, according to Rorty, Nietzsche would claim "that the self is not a substance, and that we should drop the whole idea of 'substance' - of something that cannot be perspectivalized because it has a real essence, a

Journal of French and Francophone Philosophy | Revue de la philosophie française et de langue française

Vol XX, No 2 (2012) | http://www.jffp.org | DOI 10.5195/jffp.2012.534 
privileged perspective on itself." ${ }^{4}$ And yet, according to Henry, Nietzsche claims just the opposite: the self has a real essence and cannot fail to have a privileged perspective on itself.

So far, the comparison of these two readings of Nietzsche seems simply to illustrate why no one has ever explored the connections between Henry and Rorty. Nevertheless, one might wonder how Nietzsche can inspire such diametrically opposed interpretations. Looking at Nietzsche's work, it appears that this opposition is already there. For example, while one reads in On the Genealogy of Morality: "I am who I am," which is used by Henry to underline the absolute certitude that the self has of itself, one reads in the preface to the very same text: "the motto 'everyone is furthest from himself' applies to us for ever," ${ }^{5}$ which is more in line with Rorty's interpretation. Henry and Rorty could therefore not ignore the possibility of an interpretation of Nietzsche entirely opposed to their own. Moreover, they had to explain such an opposition and justify their own interpretative choices. In other words, one should find in Henry's reading of Nietzsche the reasons for his rejection of a pragmatist conception of truth as sustained by Rorty and, conversely, one should find in Rorty's reading of Nietzsche the reasons underpinning his rejection of Henry's conception of life as "Will to power." The dialogue can now begin.

\section{Reading Rorty with Henry: The Relapse into Representation}

How does Henry explain this contradiction in Nietzsche's work? According to Henry, this contradiction is cleared up as soon as one realizes that the opposition at stake refers to the two ways of appearing. Indeed, from the way of appearing that is life, one has no choice but to be who one is. Conversely, from the way of appearing that is representation, one will necessarily be the most distant to oneself. It is therefore obvious from a Henryan point of view that Rorty only considers one way of appearing, the indigent one, and thus reproduces the traditional "monism of representation." This can be illustrated by the notion of perspective. While, according to Henry, this Nietzschean notion means that any representation is determined by affectivity, Rorty defines it as a historical recontextualization, thus understanding Nietzsche's genealogical approach as mere historicism.

What impact can this monism have on Rorty's philosophy? According to Henry, a critique of representation which does not consider the duality of appearing is condemned to fall into the "paradox of modernity," which is:

the more representation will be submitted to criticism and contested in its claim to equal reality and have the capacity to do so, the more our times will define themselves against representation and will be understood 
as 'the age of suspicion'; and the more this representation will spread, until it includes everything, the more it will appear as the basis for any possible knowledge and, therefore, any possible salvation. ${ }^{6}$

Since Rorty does not seem to recognize any other way of appearing aside from traditional representation, and simply contents himself with relativizing it, does his philosophy risk succumbing to such a paradox? ${ }^{7}$

Rorty subscribes to Nietzsche's definition of truth as a "mobile army of metaphors." From a Henryan standpoint it is clear that, as for the notion of "perspective," this Nietzschean definition of truth underlines how representations are always preceded by affectivity and thus determined by its needs. If Rorty does not manage to recognize this prior reality, one can begin to wonder who, in Rorty's philosophy, is leading this "mobile army of metaphors." Rorty answers:

Pragmatists [...] do not believe that there is a way things really are. So they want to replace the appearance-reality distinction by that between descriptions of the world and of ourselves which are useful and those which are more useful. When the question 'useful for what?' is pressed, they have nothing to say except 'useful to create a better future'. When they are asked, 'Better by what criterion?', they have no detailed answer [...]. Pragmatists can only say something as vague as: Better in the sense of containing more of what we consider good and less of what we consider bad. ${ }^{8}$

Nevertheless, if "there is no way things really are," what will determine what is useful or not, what is good or bad? One has to remember here that, according to Rorty, "anything could be made to look good or bad, important or unimportant, useful or useless, by being redescribed." ${ }^{9}$ The usefulness of preferred redescriptions seems to only depend on other redescriptions. So we find ourselves going round the following circle: we choose some representations because they are useful to us and they are useful to us because we represent them as being useful. This perfectly illustrates what Henry calls the "paradox of modernity" and the absence of any foundations in Rorty's philosophy. Insofar as Rorty himself is not claiming any foundations, there is probably nothing here for him to worry about. Nevertheless, if one adopts a pragmatist approach, one could question how this circle helps Rorty reach his particular philosophical goal, which is: to replace the traditional quest for knowledge, and its binary oppositions, with a quest for the development of imagination and empathy. This question appears all the more relevant if one recalls that, according to Henry, the opposition between subject and object constitutes the very structure of representation's way of appearing, which means that one cannot stop using

Journal of French and Francophone Philosophy | Revue de la philosophie française et de langue française Vol XX, No 2 (2012) | http://www.jffp.org | DOI 10.5195/jffp.2012.534 
these binary oppositions without breaking away from this way of appearing. Can Rorty therefore really get rid of "the baneful dualisms of the philosophical tradition"? ${ }^{10}$

Returning to Rorty's circle, one wonders whether there is any guarantee that our world is not merely one made up of linguistic redescriptions. In response, Rorty would answer that he "has no doubt that there were trees and stars long before there were statements about trees and stars." ${ }^{11}$ It thus seems that Rorty finds it useful to maintain that there is something beyond all our linguistically and historically contingent redescriptions. Rorty, without really telling us how, allows himself to step out of the circle of our redescriptions in order to postulate the existence of an independent reality. ${ }^{12}$ But in making this distinction between the physical world and linguistic redescriptions, does Rorty not revive the traditional opposition between subject and object? "[...] it is not clear," Rorty admits, "that thought is possible without using such oppositions."13 After a closer look, it appears that Rorty's anti-dualism works in the same way as his criticism of representation: he does not criticize dualisms in themselves but contents himself with relativizing the claim of describing the two terms of such dualisms separately. Will such simple relativization suffice to offer an alternative to the traditional philosophical depiction of the human being? Will it suffice in order to develop the more humanistic approach that Rorty hoped for? To answer these questions, one may look at Rorty's ideal character: the liberal ironist.

The Rortian ironist is defined as someone who is historicist and nominalist enough to see the contingency of his beliefs and desires. ${ }^{14}$ According to Rorty, any ironist, aware of being the result of past contingencies, should try to recreate oneself through redescription with one's own vocabulary and not one inherited from predecessors and imposed by a process of socialisation. However, Rorty needs to avoid linguistic idealism and to place before all our diverse redescriptions a reality which exceeds and limits them. From a Henryan stance, it is interesting to note that in order to do so Rorty invokes suffering:

The world can blindly and inarticulately crush us; mute despair, intense mental pain, can cause us to bolt ourselves out. But that sort of power is not the sort we can appropriate by adopting and then transforming its language, thereby becoming identical with the threatening power and subsuming it under our own more powerful selves. This latter strategy is appropriate only for coping with other persons - for example, with parents, gods, and poetic precursors. For our relation to the world, to the brute power and the naked pain, is not the sort of relation we have to persons. Faced with the nonhuman, the nonlinguistic, we no longer have an ability to overcome 


$$
\begin{aligned}
& \text { contingency and pain by appropriation and } \\
& \text { transformation, but only the ability to recognize } \\
& \text { contingency and pain. }{ }^{15}
\end{aligned}
$$

In invoking the theme of pain, did Rorty recognize the duality of appearing? It seems so when he claims that "there is no such thing as 'a misleading appearance of pain'."16 Aside from all our contingent redescriptions, more precisely before them, there would be an absolute revelation of the self to the self through immediate self-experience. However, Rorty then goes on to say that his claim is only the result of a "language-game" ${ }^{17}$, which means that, once again, reality has never stopped being submitted to representation. As revealed in the previous quote, suffering is therefore always conceptualised through the binary structure of representation and thus divided into two parts. One, the pain, refers to the body and connects us to animals. The other, which will be dubbed humiliation, is linguistic and specific to humans. Faithful to the philosophical tradition, Rorty keeps dividing the human being between an objective part, the body, and a subjective part, language. ${ }^{18}$ As a result, the self seems to depend only on the words it uses and this explains why Rorty attaches so much importance to redescription. Rorty writes of the "strong poet," who is the paradigmatic figure of redescription: "by describing himself in his own terms, [he] had created himself. [...] he would have created the only part of himself that mattered by constructing his own mind. To create one's mind is to create one's own language, rather to let the length of one's mind be set by the language other human beings have left behind."19 Focusing on the example of the strong poet, Rorty gives this impression that it is our singularity in itself that depends on our ability to redescribe ourselves in a completely new way. Rorty does not seem interested in the affective self experience of the subject while creating. Rather, he focuses all his analyses on the need for originality and posterity of the metaphors. ${ }^{20}$ One can now understand why Rorty might fall into the paradox of modernity whereby, after having been criticized in its claim to equal reality, representation spreads to include everything and appears as the only possible means of salvation.

Such an analysis can also be applied to Rorty's comments on solidarity. "[O]ur sense of solidarity," writes Rorty, "is strongest when those with whom solidarity is expressed are thought of as 'one of us'." ${ }^{21}$ The "us" in Rorty's philosophy refers to our community, the group of people we will help if in need. What makes us consider some people as being one of us and others as undeserving of help? "What binds societies together," writes Rorty, "are common vocabularies and common hopes."22 Here the first stumbling block appears. The ironist, by definition, is one who questions the vocabulary of one's community. The ironist is therefore a threat to the cohesion of "us":

Journal of French and Francophone Philosophy | Revue de la philosophie française et de langue française Vol XX, No 2 (2012) | http://www.jffp.org | DOI 10.5195/jffp.2012.534 
Ironism, as I have defined it, results from awareness of the power of redescription. But most people do not want to be redescribed. They want to be taken on their own terms taken seriously just as they are and just as they talk. The ironist tells them that the language they speak is up for grabs by her and her kind. There is something potentially very cruel about that claim. For the best way to cause people long-lasting pain is to humiliate them by making the things that seemed most important to them look futile, obsolete, and powerless. [...] The redescribing ironist, by threatening one's final vocabulary, and thus one's ability to make sense of oneself in one's own terms rather than hers, suggests that one's self and one's world are futile, obsolete, powerless. Redescription often humiliates. ${ }^{23}$

Due to this potential cruelty in our activity of redescription, Rorty adds the adjective "liberal" to his ideal character; the liberal considers cruelty to be the worst thing one could do. The liberal ironist is therefore not content with redescription, but is also careful that these redescriptions will not cause any cruelty and, for this reason, restricts redescription to the private sphere.

Here Rorty calls for a "sentimental education." As a "liberal," the quest for private redescription cannot be enough for the ironist. Aside from this quest, other narratives are needed to increase sensitivity to the harmful effects that certain practices and private redescriptions can have on others. Rorty speaks of increased sensitivity because, for the ironist, this attentiveness toward others cannot depend on discoveries (of the Good in human nature or of Human Rights, for example), but on a "sentimental education" which generates empathy through detailed descriptions of the suffering endured by others. These are the writings supplied by ethnologists, journalists and, especially, novelists. If one now looks into Rorty's analysis of these narratives, one finds once again, as was the case with the strong poet, the same return of dualisms and the same difficulty in breaking with tradition. To illustrate this point, one can consider Rorty's reading of the torture scene in Orwell's 1984:

Simply by being human we do not have a common bond. For all we share with all other humans is the same thing we share with animals - the ability to feel pain. One way to react to this last point is to say that our moral vocabulary should be extended to cover animals as well as people. A better way, [...], is to try to isolate something that distinguishes human from animal pain. Here is where O'Brien comes in. O'Brien reminds us that human beings who have been socialized - socialized in any language, any culture - do share a capacity which other animals lack. They can all be given a special kind of pain: They can

Journal of French and Francophone Philosophy | Revue de la philosophie française et de langue française Vol XX, No 2 (2012) | http://www.jffp.org | DOI 10.5195/jffp.2012.534 
all be humiliated by the forcible tearing down of the particular structure of language and belief in which they were socialized (or which they pride themselves on having formed for themselves). ${ }^{24}$

The distinction again emerges between pain, which is relegated to animality because it is bodily, and humiliation, which is specifically human because it is linguistic. And once more, because language is specific to humans, Rorty concentrates his analyses on humiliation.

What, more precisely, is this public vocabulary that the Rortian ironist shares with the liberal community and that ensures its cohesion? This vocabulary, writes Rorty, "consists in little more than a consensus that the point of social organization is to let everybody have a chance at self-creation to the best of his or her abilities, and that that goal requires, besides peace and wealth, the standard 'bourgeois freedoms'." ${ }^{25}$ If solidarity only relies on the strength of the "us" and this "us" relies on sharing the same vocabulary and hopes, then the creation of solidarity will consist in extending "us" to include more and more people from outside. Ultimately, the solidarity Rorty desires entails showing people who do not share our vocabulary how useful it is to have the chance to redescribe ourselves in private. Conversely, Rorty's notion of cruelty would entail preventing someone from redescribing himself in his own words. This reveals that solidarity, as Rorty refers to it, is essentially based on linguistic determination because, on the one hand, it draws its force from sharing of the same vocabulary and because, on the other hand, its ultimate goal is to make it possible for everybody to build one's own vocabulary. The same can be said for cruelty, the exact opposite of solidarity. Cruelty, on the one hand, is explained by the fact that victims and torturers do not share the same vocabulary and, on the other hand, cruelty is considered the privation or suppression of someone's ability to build his own private vocabulary. As seen previously, this focus on language does not mean that Rorty wishes to defend linguistic idealism. The extension of solidarity is only envisaged in a rich and safe society, and cruelty often uses physical abuse to reach its end. However, Rorty never really breaks with dualism and his definition of the human being is not very different from the traditional view according to which there is the body, passive and almost lacking because there is nothing to say about it, and the mind, active and freely reshaping itself. Besides, if Rorty calls for a "sentimental education," it is hard to see where the sentiments lie in such a dualistic depiction of the human being. Referring to his "sentimental education" as a "manipulation of the sentiment," 26 Rorty clearly does not consider sentiments in themselves but only sees in them useful tools for certain ends. Once again, representation still reigns.

Journal of French and Francophone Philosophy | Revue de la philosophie française et de langue française

Vol XX, No 2 (2012) | http://www.jffp.org | DOI 10.5195/jffp.2012.534 


\section{Reading Henry with Rorty: The Relapse into Metaphysics}

Henry's reading of Nietzsche allows one to imagine what his reading of Rorty could be. Is a Rortian reading of Henry conceivable, in turn? This seems far more difficult. If Rorty is rooted in representation and ignores any other way of appearing, how could he interact with Henry, whose ambition is to describe a way of appearing inaccessible to representation? Here again, the reading of Nietzsche might be helpful. How does Rorty explain the contradiction in Nietzsche's work between his "perspectivism" (understood as historicism) and his philosophy of the "Will to power"? According to Rorty, such a contradiction refers to what Heidegger called a "relapse into metaphysics." 27 More precisely, Rorty claims that Nietzsche could not refrain from aspiring to something more important than mere contingent redescriptions of philosophical history. Nietzsche would have theorized the "Will to power" with the hope of going beyond all perspectives and, in so doing, to escape from his finitude. In betraying his own perspectivism, Nietzsche would be, to quote Heidegger again, "merely an inverted Platonist." 28 Regarding Henry's understanding of Nietzschean "perspectivism" and "Will to power," such a criticism obviously misses the point. Nevertheless, while reading Henry and even while adopting his critique of representation in the name of life, one might still adopt a very similar approach to Rorty's and wonder whether Henry does not betray his own criticism.

This approach could raise the following question: if life and representation are two different, heterogeneous and opposed ways of appearing and if philosophy, as a theoretical activity, belongs to the world of representation, how can Henry claim to offer a "philosophy of life" and to reveal its "internal structure"? It is a question of submitting Henryan philosophy to its own requirements and this implies two consequences. Firstly, to examine the internal coherence of an author is of course not specific to Rorty. Many of Henry's commentators have already pursued this examination. Henry himself was always aware of the question and addressed it several times, but it will be argued here that his answers are not sufficient. Secondly, such an examination can obviously be carried out without taking on board Rorty's philosophy. Nevertheless, the results obtained here are very similar to those obtained by Rorty in examining other authors, which supports the idea that this reading could have been proposed by Rorty himself.

Henry never ignored the "extraordinary" ${ }^{29}$ difficulties encountered by his project. Nevertheless, in L'essence de la manifestation, he contents himself with saying, without any precision, that "there must be a mode of philosophy that does not harm the essential." ${ }^{30}$ The difficulties appear again in his work on Marx. Here, Henry opposes practical action (praxis), which is real because it belongs to life, and the action of thought (theory). Of course, 
the latter is also only possible in life, which remains present. Theory is thus an action, but an action which projects reality out of itself, in the space opened up by transcendence. It is therefore an action that does not produce anything $^{31}$ and a symptom of nihilism. ${ }^{32}$ This explains why Henry rejects it, as does Marx:

All Marx's critical reflection consists precisely in rejecting the action of thought as the very sign and essence of idealism. 'Rejecting' the action of thought does not mean being unaware of it, but rather affirming that it is not on a par with reality and cannot constitute it. Why is the action of thought "idealism"? Because in its objectivization, in being no more than the spread of seeing, it consists in watching. ${ }^{33}$

Workers are thereby pitted against non-workers. As a result, it is not only two ways of appearing that are at stake, but two ways of life: the authentic and the inauthentic. The problem is that philosophers are, perhaps more than anyone, pursuing precisely this action of thought, and thus living this inauthentic way of life. What can be expected then from a philosophy of life?

It is worth noting that Henry makes a distinction between the authentic and inauthentic word. In not actively doing anything, the philosopher could at least speak the truth. But how can this be possible if any word is always situated in the unreal space of transcendence? Henry answers that if it is life which makes transcendence and therefore any word possible, ultimately it is always life speaking. To use Marx's terms, ideology is "the language of real life." ${ }^{34}$ But how then can a word be inauthentic if it is always life speaking? This is possible when the word, while coming from life, forgets and denies its own origins. According to Henry, such forgetting occurs when ideological production is no longer determined by praxis. This is what happens, for instance, when some people do not need to work anymore, thanks to the division of labour made possible by the development of capitalism. Among these people, Marx identifies philosophers whose forgetting of life peaked at his time with what he termed "German ideology," characterized by its belief in itself as free and almighty, while it is just the opposite. Such ideology remains determined by life, given that it is a modification of praxis (the division of labor) that made it possible for an ideology which forgets life to emerge.

Henry's reading of Marx must then face a paradox. According to Marx, the decline of praxis that appears under capitalism thanks to the development of productive forces is what is supposed to make socialism possible. But it is precisely this decline of praxis that explains the forgetting of life. As a result, socialism seems to necessarily lead to such forgetting. Henry will later recognize this paradox:

Journal of French and Francophone Philosophy | Revue de la philosophie française et de langue française Vol XX, No 2 (2012) | http://www.jffp.org | DOI 10.5195/jffp.2012.534 
Two fundamental themes in Marx's thought are secretly in competition: the optimistic vision of a progressive liberation of man through the evolution of productive forces; the certainty, though [...], that nothing exists nor subsists if not in the hand of praxis, in touch with the burning fire of life. Whenever life lets up, harbours silt up, $[\ldots]$ everything perishes and death enters everywhere. ${ }^{35}$

This paradox does not only concern socialism. It also concerns philosophy since, according to Henry's Marx, it is the liberation of praxis that makes philosophy possible. ${ }^{36}$ Philosophy therefore also seems condemned to forget life. A closer look reveals that the competition underlined in Marx's philosophy is also present in Henry's. In the same way that Marx announced an entirely autonomous and objective mode of production, Henry claims that the genealogical thought he is pursuing is the "theory of all possible theories." ${ }^{\prime 37}$ In other words, if his philosophy seeks to express the very essence of any theory - an essence identified with the variations of praxis that constitute history, his philosophy still claims to escape the particular determinations of history, and be autonomous and objective: "when we say that every truth is related to a historical reality, we do not want to say that this very proposition is relative to the moment in which we pronounce it, or it is only true now. We want to say: it is absolutely true, everywhere and always, that truth is relative to the historical reality that constitutes it." ${ }^{\prime 38}$ Thus, while "German ideology" was still determined by the liberation of praxis, Henry's philosophy of life claims to be free from any determination of praxis.

Having said that, Henry joins Marx in saying that life only manifests itself through praxis, in touch with its "burning fire." Consequently, theory will necessarily miss its target. Henry himself admits as much when, pushing his reasoning to its limits, he calls on philosophy to "deny itself." 39 Henry writes:

It is no longer a theoretical proposition which can enlighten us and, in its transcendent meaning, provide a true statement about being, a word capable of stating what it is. The power of revelation henceforth exclusively belongs to doing, only one who does knows, in and by this doing, what it is to be, which is this doing in itself. If a theoretical proposition persists in claiming to express the truth, it does so in a very particular way, in that it no longer contains or "shows" the truth, but points outside itself and toward what is absolutely Other to itself as the place where this truth lies. It refers to a fulfilment to which it can do no more than appeal to and invoke. In a radical ontology of praxis, theory ultimately takes the form of a prescription. ${ }^{40}$ 
Henry gives the example of religious language, in which commands appear suddenly and "without any theoretical context." ${ }^{41}$ But can philosophy operate in the same way? Does it not risk relapsing into what it was criticizing: the idea that theory has some power over life and could lead us back to it?

This paradox is present in all of Henry's work. One can still find it in his later work on religion, wherein theory is again denied because it is considered inauthentic: "It is not the thought which is missing in order to access God's Revelation. On the contrary, it is only when the thought is missing, because the truth of the world is lacking, that God's self-revelation can occur." 42 In order to find salvation, one must then operate "such a radical transformation that it means a change of nature" ${ }^{\prime 3}$, and such transformation will once again lead to praxis: "The Christian ethic has portrayed itself from day one as a shift from the word, namely thought and knowledge, to action." ${ }^{44}$ What status can be given to a theory which claims that truth necessarily escapes any theory? In Incarnation, Henry seems set to face the question and answers: "According to one of Marx's too little-known reflections, thought is a way of life." ${ }^{45}$ In other words, life has never stopped being there and Henry can invite his readers to evaluate the results of his phenomenology in "comparing them to the phenomena of their own life as given in and by this life." ${ }^{46}$ There reappears with this "phenomenological imperative $^{\prime \prime 7}$ the prescriptive language already mentioned in Marx and which is supposed to lead us back to life by denying itself. Is such an answer satisfying? Firstly, one wonders if representation does not still precede life, since a negation of theory remains an act of theory. Secondly, the problem is not and never has been that of knowing whether thought is a way of life or not. The problem is that, according to Henry's own reading of Marx, this way of life is considered inauthentic, not because life is missing but because thought is a place where life denies its own essence. If thought has access to life, it is only to inauthentic life, one that has not yet accomplished the "transubstantiation" considered necessary to pass from its degenerate to its absolute form. This could explain why Henry inevitably seems to fall back into what he himself keeps criticizing.

This is again apparent when looking at how Henry seeks to define life's "internal structure." Two approaches can be identified. The first consists of simply deducing life's proprieties from the limits of representation's way of appearing. But Henry wants to go beyond this and positively determine immanence. He argues that this would be possible "when there is a withdrawal of the transcendent being and of transcendence itself in thought." ${ }^{48}$ Once again, it seems that thought needs to deny itself, but can it do so? According to Henry, this is what Nietzsche already did when focusing on the experience of suffering. Returning to this, Henry claims that such experience not only shows the primacy of life over representation, but also that, since a living being cannot escape himself, life's ordeal is an ordeal

Journal of French and Francophone Philosophy | Revue de la philosophie française et de langue française

Vol XX, No 2 (2012) | http://www.jffp.org | DOI 10.5195/jffp.2012.534 
of fundamental passivity: "passivity is the structural, ontological determination of revelation's original essence, namely of a living being considered in his internal reality." ${ }^{49}$ This distinction is key because it will allow Henry to determine more precisely the structure of life in revealing the relationship between Life and the living beings. Henry's argument works in the following way: living beings did not choose to be alive. Living beings get life without wanting it and have no power or freedom towards it. Life cannot therefore be reduced to living beings. Even if Life only exists within living beings, it always surpasses them.

This distinction is key because it allows Henry to reveal the relationship between Life and living beings. Nevertheless, even before considering these developments in themselves, one notices a strange coincidence: the experience used to demonstrate the passivity of any living being in relation to life is precisely the same one that Henry uses to define and condemn nihilism. Indeed, in order to feel this fundamental passivity toward one's own life, the living being must no longer want to be itself. And yet, this is the Henryan definition of nihilism. As a result, one could wonder whether it is not because it is through representation that the living being faces a life which, while still being his own, also seems to be a bigger, almighty and absolute Life. If so, it becomes difficult to accept Henry's distinction between living beings and Life as revealing the "internal structure" of immanence. Such a distinction seems to simply replay the initial Henryan distinction between life and representation, and the latter's lack of power towards the former. One can then imagine, as Kierkegaard did with Hegel, that Rorty would have responded to Henry's descriptions of immanence with the claim that "this is all just a thought-experiment" ${ }^{\text {" }}$, in this case an experiment of ideological production while suffering. Rorty could then do with Henry's distinction between Life and living beings what he did with Heidegger's ontological difference between Being and beings: forget the former and think that there are only the latter. ${ }^{51}$

\section{A Common Goal: "Second Birth"}

Having reached this point, a constructive dialogue between Henry and Rorty seems less likely than ever. Each one would probably reproach the other for not having gone far enough in his critique of representation and for falling back into precisely that which was criticized. Nevertheless, one can observe that their critiques are conducted at very different levels. While Henry is entirely focused on giving a coherent basis for any philosophical critique of representation, Rorty concentrates on the consequences of such a critique on the practice of philosophy. If Rorty and Henry never consider any other level of analysis aside from their own, then the current result is an inevitable one: Henry criticizes the lack of foundations in Rorty's pragmatism, while Rorty criticizes Henry's phenomenology for its selfreferential inconsistency. However, for those who consider this difference, a 
reworking would seem preferable to a direct confrontation. This would not cancel the results previously exposed, but rather reveal how both authors also show how to overcome the problems that they themselves have identified in the other. Such an approach seems all the more relevant given that both are actually criticizing representation with the same aim, to which they give the same name: a "second birth."

Henry's reading of Rorty demonstrated the importance of taking on board the question of appearing while criticizing representation. If this is not done, and if the duality of appearing is not acknowledged, one is condemned to the "paradox of modernity." This paradox reappears when Rorty uses Nietzsche to illustrate what is at stake with this idea of "second birth," which he defines as finding "distinctive words or forms for one's own distinctiveness." ${ }^{52}$ Rorty writes:

In abandoning the traditional notion of truth, Nietzsche did not abandon the idea of discovering the causes of our being what we are. He did not give up the idea that an individual might track home the blind impress all his behavings bore. He only rejected the idea that this tracking was a process of discovery. In his view, in achieving this sort of self-knowledge we are not coming to know a truth which was out there (or in here) all the time. Rather, he saw self-knowledge as a self-creation. The process of coming to know oneself, confronting one's contingency, tracking one's causes home, is identical with the process of inventing a new language - that is, of thinking up some new metaphors. ${ }^{53}$

The paradox appears here in the notion of "discovery" since, after mentioning that "Nietzsche did not abandon the idea of discovering the causes of our being what we are," Rorty adds: "he only rejected the idea that this tracking was a process of discovery." As described by Henry in his paradox, there is initially what might be considered the primacy of life: "the causes of our being what we are," a "blind impress all our behavings bore" that one can "track" and "discover," but then this "blind impress" seems to be reduced to representation, since to track it is to invent a new language. Henry, for his part, describes "second birth" as a return to praxis. In the action of doing, life does not escape itself but transforms itself by moving from its fundamental passivity into activity, thus allowing life to take possession of itself and its power, to transform the despair caused by its passivity into the pleasure of doing, to increase and intensify the sensation of itself. This is the salvation envisaged by Henry: "to restore the power and joy of living to a sick life." 54

But Henry's philosophy also allows for another understanding of Rorty's paradox. If, as Henry himself asserts, life determines our

Journal of French and Francophone Philosophy | Revue de la philosophie française et de langue française

Vol XX, No 2 (2012) | http://www.jffp.org | DOI 10.5195/jffp.2012.534 
representations, then one should not, as Henry himself mostly does, remain content with highlighting and denouncing the paradox of modernity. To do so would be to reduce such a paradox to a theoretical mistake and to therefore reduce reality to representation. One should try to better understand it from the standpoint of the living. In so doing, and despite the limits exposed, it appears that Rorty's description of "second birth" could rejoin Henry's. This interpretation seems possible when, using Nietzsche's terms, Rorty claims that redescription gives the subject the possibility of "recreating all 'it was' into 'thus I willed it'." 55 As with Henry, this seems to be all about life trying to take possession of its power, transforming and working to accept itself. If one now rereads Rorty's paradox, an alternative understanding of it becomes possible. Instead of being a symptom of nihilism, of life escaping itself in representation, the shift from "discovery" to "creation" might just illustrate the opposite: the activity of redescription's ability to operate the auto-transformation of life. Determinations of the subject have not disappeared, neither have they been denied, but they are now taken on in such a way that the subject would not want them to be different.

If Henry's philosophy helps overcome the limits that it identified in Rorty, it might also work the other way round. Henry believes that life is only likely to properly appear and be saved when denying theory and returning to praxis. The problem then lies in justifying the possibility and the point of a philosophy of life. It is interesting to note that, although pragmatism too has always condemned the primacy traditionally given to theory over practice, it does so in a different way. While Henry reverses the opposition and gives primacy to praxis and not theory, Rorty breaks with the idea that the two terms are mutually opposed. Instead, Rorty claims that theory is just one type of action among others. It neither has any ontological privilege over practical action (as in the philosophical tradition), nor is it excluded from authentic reality (as in Henry's philosophy). As just noted above, the activity of rediscription appears to be able to do what Henry confines solely to the realm of praxis: a self-transformation of life. This is confirmed in the following passage from Rorty:

the intellectual (the person who uses words or visual or musical forms for this purpose [redescription]) is just a special case - just somebody who does with marks and noises what other people do with their spouses and children, their fellow workers, the tools of their trade, the cash accounts of their businesses, the possessions they accumulate in their homes, the music they listen to, the sports they play or watch, or the trees they pass on their way to work. Anything from the sound of a word through the colour of a leaf to the feel of a piece of skin can, as 
Freud showed us, serve to dramatize and crystallize a human being's sense of self-identity. ${ }^{56}$

While Henry claims along with Marx that "theory does not do anything," Rorty suggests that to theorize is not to do nothing. The action of thought, through the efforts it requires, makes life likely to transform itself and, in Rorty's words, to aprpropriate what previously seemed inherited and alienating contingencies. From this standpoint, the absolute dimension that we seem unable to refrain ourselves from giving to certain words, even theoretical, would not mean anything but the adequacy of these words for the life of the person expressing them. One can now see why Rorty, understanding that the resonance of a word is unique to each human being, did not want to find the words that would describe life in a way that would be true for everyone, but sought instead to ensure people the freedom to redescribe themselves and to choose the words with which they will live their life.

\section{Conclusion}

A constructive dialogue between Henry's phenomenology and Rorty's pragmatism did not at first seem very likely, as confirmed by the attempt to see how Henry might read Rorty and, conversely, how Rorty would read Henry. In both scenarios, the result would be the same: each would consider that the other has not been faithful to his claim of breaking with the philosophical tradition and thus ultimately reproduces its limits. Nevertheless, these analyses were carried out on different levels: while Henry focuses on giving coherent grounds for any philosophical critique of representation, Rorty is occupied with the consequences of such a critique on philosophy itself. When one considers this difference, there emerges the possibility of a new dialogue which does not cancel out the previous one, but does help to overcome some of the obstacles it identified. As a result, this article shows that Henry's phenomenology is fundamental for the recognition of what Rorty calls the "human being's sense of self-identity," while it falls to Rorty's pragmatism to ensure that, as Henry hoped, there is "a mode of philosophy that does not harm the essential."

Journal of French and Francophone Philosophy | Revue de la philosophie française et de langue française

Vol XX, No 2 (2012) | http://www.jffp.org | DOI 10.5195/jffp.2012.534 
1 This article does not aim to evaluate the veracity of these claims and, for example, whether Richard Rorty can be considered a pragmatist or not. Here, the terms "pragmatism" and "phenomenology" will be used as Rorty and Henry use them.

${ }^{2}$ Friedrich Nietzsche, On the Genealogy of Morality, trans. Carol Diethe (New York: Cambridge University Press, 2007), 89-90. Quoted in Michel Henry, Généalogie de la psychanalyse (Paris: Presses Universitaires de France, 1985), 297.

${ }^{3}$ Richard Rorty, Contingency, Irony and Solidarity (New York: Cambridge University Press, 1989), 27.

${ }^{4}$ Rorty, Contingency, Irony and Solidarity, 106.

${ }^{5}$ Nietzsche, On the Genealogy of Morality, 3.

${ }^{6}$ Author's translation from French: “plus la représentation sera soumise à la critique et contestée dans sa prétention de s'égaler à la réalité et de pouvoir le faire, plus notre époque se définira contre elle et se comprendra comme 'l'ère du soupçon', et plus l'emprise de cette même représentation s'étendra, au point de tout inclure en elle, plus elle apparaîtra comme le principe de toute connaissance et par là même de tout salut possible." Cf. Henry, Généalogie de la psychanalyse, 194.

7 One might wonder if Rorty's insistence on contingency is not in opposition with this paradox and its idea that representation has become the "principle of any possible knowledge." It is important to remember here that Rorty does not question representation as a way of appearing. Also, from a Henryan stance, the Rortian philosophy of contingency simply confirms the indigence of representation. As for making representation the basis for any possible salvation, that is what will emerge later in this article.

${ }^{8}$ Richard Rorty, Philosophy and Social Hope (New York: Penguin Books, 1999), 27-28

9 Rorty, Contingency, Irony and Solidarity, 7. If this claim does not necessarily appear Rortian in that part of the text, it does on page 73.

10 Rorty, Philosophy and Social Hope, 29.

${ }^{11}$ Rorty, Philosophy and Social Hope, 58.

12 In order to establish that reality exists independently from our linguistic redescriptions of it, reality needs to be given through a mode other than representation. If this mode does not bring knowledge in its traditional meaning, one still has to admit that there is a certain kind of knowledge, even if it is not possible to account for this knowledge without language. This is what Rorty seems to assume when he writes: "even if there is no Way the World Is, even if there is no such thing as 'the intrinsic nature of reality', there are still causal pressures. These 
pressures will be described in different ways at different times and for different purposes, but they are pressures none the less" (Ibid., 33). From a Henryan standpoint, it is clear that these "causal pressures" draw their reality from the living, not because the living being constitutes external reality, but because only that which experiences itself is likely to feel something, such as pressure for example. But what reality can Rorty give to those pressures if he does not recognize any other way of appearing aside from representation?

${ }^{13}$ Rorty, Philosophy and Social Hope, 47.

14 One notices here once more that, in Rorty's philosophy, beliefs and desires do not refer to anything other than linguistic redescriptions, since their contingency is enough to make beliefs and desires contingent. To criticize Rorty for only considering representation (or language) to the detriment of affectivity is not new. Such criticism has even been developed inside the pragmatist tradition itself. Richard Shusterman, for example, already did so and one can question whether the Henryan reading suggested here contributes anything new. A closer look reveals that Henry offers a new perspective. For Henry, the problem is not so much what is considered (the body or language), but the way it is considered (through representation's or life's way of appearing). A philosophy focusing on bodily experiences will therefore not necessarily be more concrete or acknowledge better affectivity. For example, Henry would probably reproach R. Shusterman for remaining in representation's way of appearing and subsequently doing the same thing for which he criticizes Rorty. This can be illustrated with reference to the "self." According to the Henryan reading of Rorty imagined here, the latter seems to reduce the self to its representations. R. Shusterman underlines the same problem when he writes: "to abandon the notion of a firmly distinctive self, one that is not continuously supplanted by endless redescription in new vocabularies acquired from others, is to render the prospect of distinctive self-creation problematic at the least" (Richard Shusterman, Pragmatist Aesthetics: Living Beauty, Rethinking Art (Cambridge: Blackwell Publishers, 1992), 248). But Shusterman does not seem to offer any other alternative when, just a few lines later, he adds: "For, having rightly abandoned essentialism, we can only constitute the self in terms of narrative about it, as Rorty himself urges. It follows that the unity and coherence of the self will depend on the unity and coherence of its narratives" (Ibid., 248-249).

15 Rorty, Contingency, 40. R. Shusterman uses the same passage but interprets it like this: "But though he [Rorty] strives to exclude the substantial from the

Journal of French and Francophone Philosophy | Revue de la philosophie française et de langue française Vol XX, No 2 (2012) | http://www.jffp.org | DOI 10.5195/jffp.2012.534 
significantly human and aesthetics [...], the non-discursive returns with a vengeance in the form of pain" (Shusterman, Pragmatist Aesthetics, 258). Shusterman adds: "For it is very sad and unsatisfying aestheticism which affirms the persuasive presence of pain but ignores the sensual bodily pleasures" (Ibid, 259). Once again, one can ask how Shusterman is more likely to consider "our non-linguistic experience" if "we can only constitute the self in terms of narrative about it." Shusterman seems to use "sensual bodily pleasure" for the same reason than Rorty uses "pain": to give some reality to a self made up only of narratives.

16 "There is no such a thing as 'a misleading appearance of pain' [...]." Richard Rorty, Philosophy and the Mirror of Nature (Princeton: Princeton University Press, 2009), 32. This is perfectly aligned with Henry's reading of Descartes' “at certe videre videor" which would demonstrate that, for a moment, Descartes was aware of the duality of appearing.

17 "Following Wittgenstein, we shall treat the fact that there is no such a thing as 'a misleading appearance of pain' not as a strange fact about a special ontological genus called the mental, but just as a remark about the language-game - the mark that we have the convention of taking people's word for what they are feeling. From this 'language-game' point of view, the fact that a man is feeling whatever he thinks he's feeling has no more ontological significance than the fact than the Constitution is what the Supreme Court think it is, or that the ball is foul if the umpire thinks it is" (Ibid.). Rorty responds here to those who wish to deduce a nonphysical ontological entity (the mental) from the fact that pain has a phenomenological status. From a Henryan point of view, one can perfectly understand Rorty's doubts about the validity of such a deduction. Nevertheless, nothing obliged Rorty to reduce the phenomenal to a representation, whether it is an empirical or a conceptual one, as do his opponents and the philosophical tradition. Given that he does not explore any alternative to this traditional definition of the phenomenal, Rorty has no other choice than to use it in order to think through the obviousness of pain with the following result: this obviousness becomes itself contingent and is reduced to a simple "convention." In other words, if to feel pain is so obvious, it is only because we consider it useful to think it is so. And yet, the opposite would have been quite a relief.

18 This is also apparent in Shusterman's philosophy. Having replaced the Rortian use of "pain" with "sensual bodily pleasure," the self proposed by Shusterman is also made up of two parts: "narratives" and "non-linguistic experience" (pleasure preferably). As was the case in Rorty's philosophy, it is not the mind-body dualism 
that is questioned, but only the possibility of separating the two parts: "Though such somatic experience may be irreducible to linguistic formulation, its contribution to the formation of mind and selfhood cannot be denied and indeed reveals the fundamental wrongheadedness of considering mind and body as separate entities and of identifying the self narrowly with the former. Though Rorty correctly insists that the self is structured by the vocabulary it inherits, Foucault is equally right in stressing that it is also the product of disciplinary practices inscribed on the body" (Shusterman, Pragmatist Aesthetics, 259-260).

${ }^{19}$ Rorty, Contingency, Irony and Solidarity, 27.

20 Originality because, while all humans have the potential to redescribe themselves, it still needs to be done in a new way so as to be truly singular. Posterity because the subject, not finding his singularity in himself, hopes to obtain it from the recognition of others. As a result, only well-known "strong poets" would have singularity. It is probably in order to avoid this that Rorty's reading of Nietzsche is followed by a reading of Freud; because, as Philip Rieff puts it, "Freud democratized genius by giving everyone a creative unconscious" (Ibid., 36). Singularity is thus saved by the "unconscious." Despite the fact that singularity remains reduced to our ability to create metaphors, it is interesting to note here that, according to Henry, this concept of the "unconscious" is only the sign of an inability to consider life.

21 Rorty, Contingency, Irony and Solidarity, 191.

22 Rorty, Contingency, Irony and Solidarity, 86.

${ }^{23}$ Rorty, Contingency, Irony and Solidarity, 89-90.

24 Rorty, Contingency, Irony and Solidarity, 177.

${ }^{25}$ Rorty, Contingency, Irony and Solidarity, 84.

${ }^{26}$ Richard Rorty, "Human Rights, Rationality, and the Sentimentality," in Truth and Progress: Philosophical Papers, volume 3 (New York: Cambridge University Press, 1998), 176.

27 Rorty, Contingency, Irony and Solidarity, 107.

${ }^{28}$ Rorty, Contingency, Irony and Solidarity, 107.

29 Michel Henry, L'essence de la manifestation (Paris: Presses Universitaires de France, 2003), 55.

${ }^{30}$ Author's translation from French: “[...] si la philosophie est seconde par rapport à la vie, il doit cependant exister un mode de philosopher qui ne porte point préjudice à l'essence" (Henry, L'essence de la manifestation, 56).

Journal of French and Francophone Philosophy | Revue de la philosophie française et de langue française Vol XX, No 2 (2012) | http://www.jffp.org | DOI 10.5195/jffp.2012.534 
31 Author's translation from French: "la théorie ne fait rien." Michel Henry, Marx I, Une philosophie de la réalité (Paris: Gallimard, 1976), 353.

32 For example: “la pensée théorique de l’humanité puise sa motivation dernière dans la faiblesse et se laisse déterminer par elle" (Henry, Généalogie de la psychanalyse, 312).

33 Author's translation from French: "Toute la réflexion critique de Marx [...] consiste justement à rejeter l'action de la pensée comme le signe même et l'essence de l'idéalisme. 'Rejeter' l'action de la pensée ne signifie nullement la méconnaître mais affirmer qu'elle ne se situe pas au plan de la réalité et ne peut la constituer. Pourquoi l'action de la pensée est-elle 'idéalisme'? Parce que s'accomplissant comme objectivation, n'étant rien d'autre que le déploiement du voir, elle consiste à regarder" (Henry, Marx I, 354). See also: "il est absurde de vouloir considérer comme une 'pratique' l'activité théorique et de la baptiser par exemple 'pratique théorique'. C'est détruire toute la problématique de Marx de la fondation de l'idéologie pour retomber dans celle-ci" (Ibid., 403).

${ }^{34}$ Author's translation from French: "la langue de la vie réelle" (Ibid., 403).

35 Author's translation from French: "Deux thèmes fondamentaux de la pensée de Marx entrent secrètement en concurrence: la vision optimiste de la libération progressive de l'homme promise par l'évolution des forces productives; la certitude cependant [...] que rien n'existe ni ne subsiste si ce n'est dans la main de la praxis, au contact du feu brûlant de la vie. Que celle-ci relâche un instant son effort, les ports s'ensablent, [...] tout dépérit et la mort s'installe partout” (Michel Henry, "Préalables philosophiques à une lecture de Marx," in Phénoménologie de la vie, tome III: De l'art et du politique (Paris: Presses Universitaires de France, 2004), 61). 36 “c'est au moment où la conscience conquiert son autonomie et passe 'à la formation de la théorie pure, de la théologie, de la philosophie, de la morale, etc.', au moment où elle s'émancipe ou du moins se figure qu'elle y parvient, où elle 'peut réellement s'imaginer qu'elle est autre chose que la conscience de la pratique existante' que sa dépendance à l'égard de cette pratique est la plus évidente, puisque l'émergence de la conscience théorique est mise au compte de la division du travail, c'est-à-dire encore, d'une détermination de vie subjective originelle" (Henry, Marx I, 381-382).

37 Author's translation from French: "Théorie de toutes les théories possibles" (Henry, Marx I, 478).

38 Author's translation from French: “Lorsque nous disons que toute vérité est relative à la réalité historique, nous ne voulons pas dire que cette proposition elle- 
même est relative au moment où nous la formulons, n'est vraie que maintenant. Nous voulons dire: il est vrai absolument, partout et toujours, que toute vérité est relative à la réalité historique qui la fonde" (Henry, Marx I, 474).

${ }^{39}$ Henry, Marx I, 365.

40 Author's translation from French: “Ce n'est plus une proposition théorique, dès lors, qui peut nous éclairer et, par sa signification transcendante, porter sur l'être un témoignage véridique, une parole susceptible de dire ce qu'il est. Le pouvoir de révélation appartient désormais et de façon exclusive au faire, seul celui qui fait sait, par ce faire toutefois et en lui, ce qu'il en est de l'être, qui est ce faire luimême. Si une proposition théorique subsiste dans sa prétention à exprimer la vérité, c'est d'une manière très particulière, en tant qu'elle ne la contient plus et ne la donne plus à 'voir' en elle-même, mais indique hors d'elle et comme l'autre absolu d'elle-même le lieu où cette vérité s'accomplit, renvoie à cet accomplissement pour lequel elle ne peut rien sinon en appeler à lui et l'invoquer. Dans une ontologie radicale de la praxis, la théorie revêt en fin de compte la forme d'une prescription" (Henry, Marx I, 364).

${ }^{41}$ Henry, Marx I, 364.

42 Author's translation from French: “Ce n'est pas la pensée qui nous manque pour accéder à la Révélation de Dieu. Bien au contraire, c'est seulement quand la pensée fait défaut, parce que la vérité du monde est absente, que peut s'accomplir [...] l'auto-révélation de Dieu [...]" (Michel Henry, C'est moi la vérité (Paris: Seuil, 1996), 39).

43 Author's translation from French: “Transformation si radicale qu'elle signifie proprement un changement de nature, une sorte de transsubstantiation" (Michel Henry, Paroles du Christ (Paris: Seuil, 2002), 31).

44 Author's translation from French: “Ainsi l'éthique chrétienne se présente-t-elle d'entrée de jeu comme un déplacement de l'ordre de la parole, c'est-à-dire aussi bien de la pensée et de la connaissance, à celui de l'agir" (Henry, C'est moi la vérité, 209).

45 Author's translation from French: “ Selon une parole trop peu méditée de Marx, la pensée est un mode de la vie” (Michel Henry, Incarnation (Paris: Seuil, 2000), 130).

${ }^{46}$ Henry, Incarnation, 265.

${ }^{47}$ Henry, Incarnation, 265.

Journal of French and Francophone Philosophy | Revue de la philosophie française et de langue française Vol XX, No 2 (2012) | http://www.jffp.org | DOI 10.5195/jffp.2012.534 
48 Author's translation from French: "quand s'opère dans la pensée le retrait de l'être transcendant et de la transcendance elle-même" (Henry, L'essence de la manifestation, 351).

${ }^{49}$ Author's translation from French: "La passivité est la détermination ontologique structurelle de l'essence originaire de la révélation, c'est-à-dire de l'être lui-même considéré dans sa réalité interne [...]" (Henry, L'essence de la manifestation, 366).

50 This anecdote mentioned by Rorty: "Kierkegaard said that if Hegel had prefaced the Science of Logic with 'This is all just a thought-experiment', he would have been the greatest thinker who ever lived" (Rorty, Contingency, Irony and Solidarity, 104).

51 "If, as I do, one forgets about Being and thinks that beings are all there are, then [...]" (Rorty, Contingency, Irony and Solidarity, 113).

52 Rorty, Contingency, Irony and Solidarity, 24.

53 Rorty, Contingency, Irony and Solidarity, 27.

54 Author's translation from French: "rendre une vie malade à son pouvoir et au bonheur de vivre" (Michel Henry, "Souffrance et vie," in Phénoménologie de la vie, tome I (Paris: Presses Universitaires de France, 2003), 156).

${ }^{55}$ Rorty, Contingency, Irony and Solidarity, 29.

${ }^{56}$ Rorty, Contingency, Irony and Solidarity, 37. 